\title{
Landscape opening and herding strategies: Carbon isotope analyses of herbivore bone collagen from the Neolithic and Bronze Age lakeshore site of Zurich-Mozartstrasse, Switzerland
}

\author{
Thomas Doppler ${ }^{a,{ }^{*}}$, Claudia Gerling $^{a}$, Volker Heyd ${ }^{b}$, Corina Knipper ${ }^{c}$, Thomas Kuhn ${ }^{d}$, \\ Moritz F. Lehmann ${ }^{d}$, Alistair W.G. Pike ${ }^{e}$, Jörg Schibler ${ }^{a}$
}

\footnotetext{
${ }^{a}$ University of Basel, Institute of Prehistory and Archaeological Science, Spalenring 145, 4055 Basel, Switzerland

${ }^{\mathrm{b}}$ University of Bristol, Department of Archaeology \& Anthropology, 43 Woodland Road, Bristol BS8 1UU, United Kingdom

${ }^{c}$ Curt-Engelhorn-Centre Archaeometry, D6, 3, 68159 Mannheim, Germany

d University of Basel, Geosciences, Biogeochemistry, Bernoullistrasse 39, 4056 Basel, Switzerland

${ }^{\mathrm{e}}$ University of Southampton, Department of Archaeology, Avenue Campus, Highfield Road, Southampton SO17 1BF, United Kingdom

* Corresponding author: thomas.doppler@unibas.ch
}

\begin{abstract}
Carbon isotope analysis $\left(\delta^{13} \mathrm{C}\right)$ was performed on collagen extracted from 54 domestic cattle (Bos taurus) and 20 red deer (Cervus elaphus) bones from the Neolithic (3913-2586 BC) and Bronze Age (1950-950 cal. BC) layers of the lakeshore site Zurich-Mozartstrasse located in the lower Lake Zurich basin, Switzerland. We observed shifts in the $\delta^{13} \mathrm{C}$ of both domestic cattle and red deer over two millennia. Mean $\delta^{13} \mathrm{C}$ values of red deer changed from $-24.1 \pm$ $0.7 \%$ to $-22.5 \pm 0.3 \%$, while mean $\delta^{13} \mathrm{C}$ values of domestic cattle showed minor changes from $-22.7 \pm 1.3 \%$ o to $-22.1 \pm 0.3 \%$. Our data suggest that in the early $4^{\text {th }}$ millennium $B C$ the landscape was densely forested with red deer feeding in closed habitats and cattle grazing in more open landscapes. Forest was also a food resource for some young cattle as indicated by the lower $\delta^{13} \mathrm{C}$ values of non-adult relative to adult animals. This points to a greater diversity of herding strategies and feeding techniques compared to the later periods. The landscape was still rather forested towards the mid- $3^{\text {rd }}$ millennium $\mathrm{BC}$, with no obvious changes in the habitat use of the large herbivores. However, the carbon isotopes suggest a clearly reduced forest cover in the $2^{\text {nd }}$ millennium BC with red deer using similar open feeding grounds as domestic cattle. Our study demonstrates that the stable carbon isotope composition of
\end{abstract}


archeological bone material from large herbivores can provide integrative constraints on paleoenvironmental and vegetation changes, prehistoric animal management and land-use. Keywords: Prehistory, land-use, environmental change, canopy effect, domestic cattle, red deer

\section{Introduction}

Lakeshore settlements are amongst the best investigated archeological sites worldwide. Due to burial in waterlogged, and essentially anoxic, lake sediments, the preservation of (organic) finds and features is exceptional and a broad range of scientific approaches have been applied to study this legacy of our past (Menotti, 2004; 2012; Menotti and O'Sullivan, 2013). Dendrochronological investigation on almost pristine timber allows precise tree-ring dating of residential structures and the reconstruction of settlement histories (e.g. Hafner, 1993; Leuzinger, 2000; Schlichtherle et al., 2011). Within this framework, rich faunal remains provide detailed insights into subsistence strategies, and represent valuable proxies to be used for paleoenvironmental reconstructions (e.g. Hüster-Plogmann and Schibler, 1997; DeschlerErb and Marti-Grädel, 2004; Chiquet, 2012).

While there is extensive knowledge about the actual settlement sites, little is known about the immediate surroundings of the lake dwellings in terms of subsistence activities beyond settlement frontiers. Some important conclusions have however been drawn using bioarcheological data. For example, it was shown that hunted animals, gathered plants and wood resources were of great importance in these settlements, and evidence from off-site pollen analyses suggests that the settlements' surroundings were used for agricultural activities (e.g. Schibler et al., 1997; Schibler and Jacomet, 1999; Jacomet et al., 2004; Billamboz, 2012; Clarke, 2013). Nevertheless, these insights are rather sporadic, and the hinterland of lake dwellings remains a blind spot in many respects, despite its undoubted relevance to subsistence behavior and as potential source of information in the context of regional mobility patterns (e.g. Bleicher, 2009; Ebersbach, 2013).

The analysis of stable isotope ratios in archeological mammal bones is a promising tool for complementing archeological research of the settlements' hinterland. Carbon isotope analyses have widely been used to distinguish between a diet predominated by plants exhibiting either $\mathrm{C}_{3}$ or $\mathrm{C}_{4}$ photosynthetic pathways, and to evaluate the contribution of terrestrial versus marine resources in human diet (e.g. Richards et al., 2006; Fischer et al., 2007; Oelze et al., 2011; 
Cerling et al., 2013). As $\delta^{13} \mathrm{C}$ values for bone collagen extracted from large herbivores are assumed to directly reflect the herbivores' diet, they can also be used as a proxy for vegetation conditions, e.g. the water availability and associated stomatal control, the dominance of specific plant types, or the degree of habitat closure, i.e. canopy (Drucker et al., 2003; NoeNygaard et al., 2005; Drucker et al., 2008; Drucker et al., 2011; Bonafini et al., 2013; Gąsiorowski et al., 2014; Stevens et al., 2014). The canopy effect produces a gradient of leaf $\delta^{13} \mathrm{C}$ from ground to canopy of forested areas, with most ${ }^{13} \mathrm{C}$-depleted plants near the ground, which can be explained by an enhanced recycling of ${ }^{13} \mathrm{C}$-depleted $\mathrm{CO}_{2}$ in the forest, elevated $\mathrm{C}$ isotope fractionation due to photosynthesis under low light conditions, and other physiological mechanisms (e.g. Vogel, 1978; van der Merwe and Medina, 1991). The depleted $\delta^{13} \mathrm{C}$ is passed along the food chain from vegetation into animal tissues, such as bone collagen. More negative $\delta^{13} \mathrm{C}$ values indicate feeding grounds with closed canopy. Hence, differences in carbon isotope values can help to distinguish between animals grazing in dense forests and those obtaining their food in open environments (e.g. Drucker et al., 2003; Drucker et al., 2008; Drucker et al., 2011). However, the isotopic threshold for distinguishing between grazing in densely forested versus open environment is ecosystem-dependent (Stevens et al., 2006), and may fluctuate with local climate conditions, atmospheric $\mathrm{CO}_{2}$ concentration and atmospheric $\delta^{13} \mathrm{C}$ value during a specific archeological period. In previous studies $\delta^{13} \mathrm{C}$ cut-off values of $-22.5 \%$ (Drucker et al., 2003) and -22.0\%o (Drucker et al., 2011) were suggested by analyzing red deer bone collagen from temperate and periarctic environments of the northern hemisphere.

We applied stable carbon isotope analyses to Neolithic and Bronze Age domestic cattle (Bos taurus) and red deer (Cervus elaphus) collagen samples in order to explore environmental conditions, changes in habitat use and livestock management in the temperate deciduous ecosystem of the lower Lake Zurich region. Our study complements archeobiological research showing human impact and exploitation of the lake's hinterland throughout the Neolithic (Jacomet et al., 1989; Schibler et al., 1997).

\section{Archeological context}

We focus on the well-described site of Zurich-Mozartstrasse, which is located at the northern end of Lake Zurich in Switzerland (Figure 1). An area of $2700 \mathrm{~m}^{2}$ of the settlement was excavated in 1981 and 1982. The stratigraphy of this site is more than $2 \mathrm{~m}$ deep, and indicates repeated occupation and abandonment episodes of the same place. The settlement layers cover a time span from the early $4^{\text {th }}$ to the $2^{\text {nd }}$ millennium $\mathrm{BC}$, and thus provide an archeological 
record of more than 2000 years of human activity (Figure 2; Gross et al., 1987; Gross et al., 1992; Bleuer and Hardmeyer, 1993; Schmidheiny, 2011; Ebersbach et al., 2015). Six mainly dendrochronologically dated layers were attributed to the Cortaillod, Pfyn, Horgen, and Corded Ware periods (3913-2586 BC) and the Bronze Age (1950-950 cal. BC) (Figure 3).

The archeozoological remains of these layers have been extensively studied in previous work (Hüster-Plogmann and Schibler, 1997), and allowed detailed insights into the longer-term variation of the relative proportions of domestic versus wild animals, particularly with regard to large herbivores. Between the late $5^{\text {th }}$ and the early $3^{\text {rd }}$ millennium BC, the relative quantity of domestic animals (cattle, pig, sheep, and goat) with respect to wild animals varied substantially between $10 \%$ and $95 \%$ (Figure 4 ). Most notably, in the $37^{\text {th }}$ century BC red deer were most intensively hunted so that the share of domestic animal remains declined to $10 \%$. With regard to domestic animals, cattle were most important between ca. 4000 and $3300 \mathrm{BC}$, even though herd sizes were small especially in the early $4^{\text {th }}$ millennium BC. This was succeeded by a period of intensified pig husbandry, followed by a period of enhanced domestic cattle, sheep and goat husbandry from the $28^{\text {th }}$ century BC onwards (HüsterPlogmann and Schibler, 1997). Wild animals preferring open forests and forest edges such as fox (Vulpes vulpes) and hare (Lepus europaeus), are frequent from 3300 BC onwards. The shift from a natural landscape (primeval forest) to a man-made cultural landscape is also supported by archeobotanic records that evidence the presence of specific wild plants. There is clear indication for the presence of widespread deforested areas (agricultural fields and fallow grounds) in the surrounding of the settlements during the late Corded Ware phase. In connection with growing herd sizes of domestic animals in the $3^{\text {rd }}$ millennium BC these deforested areas, but also forests, were intensively used for pasturing (Hüster-Plogmann et al., 1999).

\section{Material and methods}

A total of 74 animal bones from 54 domestic cattle and 20 red deer and from four different layers were analyzed. The oldest Layers 6 and 5 (Cortaillod) date back to between 3913 and 3861 BC, whereas Layer 2 (Corded Ware) dates between 2625 and 2568 BC (Ebersbach et al., 2015). Layer 1 represents the Bronze Age, but is less precisely dated. It comprises settlement phases from the Early Bronze Age (between ca. 1950 and 1550 cal. BC), the Middle Bronze Age (between ca. 1504 and 1490 BC) and the Late Bronze Age (between ca. 1050 and $950 \mathrm{cal}$. BC) (Bleicher, 2011). The prime objective of this study was to compare the oldest with the youngest layers. The data from Layers 4 (Pfyn) and 3 (Horgen) are not 
discussed here. Although subdivided originally into separate units, Layers 6 and 5 are treated as a single stratigraphic entity in the discussion and interpretive conclusions below, as it is now confirmed that they both belong to the same chronological phase (Ebersbach et al., 2015). Even though Layer 1 contains multiple Bronze Age settlement phases, it is considered here as one single stratigraphic entity.

Sample specimens were identified and assigned morphologically to specific macro-vertebrate faunal species. They were differentiated by skeletal element and body part in order to avoid double measurements of the same individuals. Collagen was analyzed from nine cattle and five red deer specimens from Layer 6, ten cattle specimens from Layer 5, 19 cattle and ten red deer specimens from Layer 2, and 15 cattle and five red deer specimens from Layer 1 (Table 1). Sampled skeletal elements have been investigated for age at death determination at the Institute of Prehistory and Archaeological Science (IPAS), University of Basel, applying a multi-proxy approach following the methods of Ducos (1968), Habermehl (1975), Grant (1982), Blaise (2009), Gillis (2012) and IPAS (Altersbestimmung) for domestic cattle, and Riglet (1977), Habermehl (1985) and von Raesfeld and Reulecke (1988) for red deer. We selected 23 non-adult and 31 adult domestic cattle samples as well as four non-adult and 16 adult red deer samples for bone collagen stable carbon isotope analysis. For each layer, both non-adult and adult animal specimens were considered, yet somewhat more non-adults were analyzed for the oldest layers, due to the fact that more bones of non-adult cattle were preserved in these layers. All but three samples were taken from jawbones as the age estimation using toothed jawbones is more accurate than for long bones. Based on intergrowth characteristics and general appearance, the three radius fragments sampled were assigned to adult red deer.

Collagen extraction followed the methodology outlined in Longin (1971), Ambrose (1990) and Oelze et al. (2011) with omission of the ultrafiltration step of which the benefit is rather uncertain (cf. Jørkov et al., 2007; Sealy et al., 2014). Chunks of bone were cut and the surfaces removed using dental cutting and milling equipment. Between 200 and $1000 \mathrm{mg}$ of sample material was demineralized in $10 \mathrm{ml}$ of $0.5 \mathrm{M} \mathrm{HCl}$ at $4^{\circ} \mathrm{C}$ for two weeks with daily shaking, occasional exposition to room temperature, and an acid bath change after one week. Samples were then rinsed with ultrapure water to restore neutral $\mathrm{pH}$ before treatment with 10 $\mathrm{ml}$ of $0.1 \mathrm{M} \mathrm{NaOH}$ at $4^{\circ} \mathrm{C}$ for about 24 hours in order to remove any humic substances. After rinsing to reach neutral conditions again, $4 \mathrm{ml}$ of ultrapure water, and $200 \mu \mathrm{l}$ of $0.5 \mathrm{M} \mathrm{HCl}$ 
were added and the samples gelatinized at $70^{\circ} \mathrm{C}$ for 48 hours. Finally, the solution containing the dissolved collagen was filtered using Ezee Filter separators (Elkay, UK) with pore size 60$90 \mu \mathrm{m}$ to remove any remaining particulate organic remnants, frozen at $-20^{\circ} \mathrm{C}$, and lyophilized for 48 hours. Between 0.5 and $1 \mathrm{mg}$ of freeze-dried sample were weighed into tin capsules, and the elemental and isotope composition was determined by Elemental Analysis Isotope Ratio Mass Spectrometry (EA-IRMS) using an INTEGRA2 instrument (Sercon Ltd., Crewe, UK) at the Department of Environmental Sciences, University of Basel. All samples were analyzed in duplicate. Ultra high purity helium of grade 5.0 at a flow rate of $55 \mathrm{ml} / \mathrm{min}$ was used as carrier gas. The combustion and reduction reactors were operated at $1010^{\circ} \mathrm{C}$ and $600^{\circ} \mathrm{C}$, respectively. Gas chromatographic separation of the combustion and reduction products $\mathrm{N}_{2}$ and $\mathrm{CO}_{2}$ was achieved on a column packed with Carbosieve $\mathrm{G}$ (stainless steel, 50 cm, 1/4" OD, 60/80 mesh; Analytical Columns, Croydon, UK). An EDTA laboratory standard $\left(\square{ }^{13} \mathrm{C}=-30.25 \%\right.$ ), which has been isotopically calibrated against international reference materials, was measured after intervals of 10 samples throughout each of the eight analytical sequences to check and correct for instrumental drift. This EDTA laboratory standard was also used to check and correct for instrument induced amount linearity by measuring groups of four standards weighed in at different amounts $(0.25,0.5,1.0,1.5 \mathrm{mg})$ at the beginning, in the middle, and at the end of each analytical sequence. In addition, the international reference material IAEA-CH-6 ( $\square{ }^{13} \mathrm{C}=-10.449 \%$ ) was measured at the beginning, in the middle, and at the end of each analytical sequence. The reproducibility (1 $\square$ ) for the IAEA-CH-6 and EDTA standards over all eight analyzed sequences was $0.26 \%$ o $(n=23)$ and $0.24 \%$ ( $(n=110)$, respectively. The raw carbon isotope data are normalized to the VPDB (Vienna Pee Dee Belemnite) scale by means of a two-point calibration based on the IAEA-CH-6 and EDTA standards in each analytical sequence. The final calibrated results are reported as $\delta^{13} \mathrm{C}$ in \%o relative to VPDB. We also analyzed replicates $(n=8)$ of a selected bone collagen sample, for which a larger quantity of material was available, in two analytical sequences separated by a time period of six months to test the analytical precision for a representative example of our sample material. The mean $\delta^{13} \mathrm{C}$ for all eight analyses was $-22.9 \%$ with a reproducibility $(1 \sigma)$ of $0.1 \%$.

The bone collagen yields, as well as the carbon and nitrogen contents of the bone collagen and the atomic $\mathrm{C} / \mathrm{N}$ ratios of the samples were used to verify the preservation of the archeological specimens and the purity of the extracted collagen which may bias stable isotope analysis. Collagen yields $\geq 1.0 \%$, carbon contents between 30 and $46 \%$, nitrogen contents between 10 and $17 \%$, as well as atomic $\mathrm{C} / \mathrm{N}$ ratios between 2.9 and 3.6 were considered as thresholds for 
good collagen preservation (DeNiro, 1985; Ambrose, 1990; van Klinken, 1999). All but one sample (MOZ 81) fulfilled the criteria of good collagen preservation, and are included in the subsequent discussion.

\section{Results}

The interpretation of our data is based on 53 domestic cattle and 20 red deer specimens. Statistical significance with respect to elemental and isotopic differences between groups of samples was tested using the approaches of Kruskal-Wallis (KW) and Mann-Whitney (MW). Relevant statistics are outlined in Table 2.

Collagen yields range between $1.0 \%$ and $18.6 \%$ for domestic cattle, and between $7.0 \%$ and $15.2 \%$ for red deer respectively, with no significant differences between the archeological layers, animal species or age groups. Independent of the faunal species, $\mathrm{C} / \mathrm{N}$ ratios were quite invariant with values between 3.2 and 3.4 for domestic cattle and between 3.2 and 3.3 for red deer. Collagen carbon content for domestic cattle varied between $37.5 \%$ and $45.7 \%$, collagen nitrogen content ranged between $13.5 \%$ and $16.1 \%$. For red deer, the $\mathrm{C}$ ranged between $39.5 \%$ and $45.5 \%$ and $\mathrm{N}$ contents ranged between $14.0 \%$ and $16.0 \%$. No significant differences in $\% \mathrm{C}$ and $\% \mathrm{~N}$ could be discerned between faunal species, whereas significant differences were observed when comparing adult and non-adult domestic cattle (MW, $\mathrm{p}=0.005$ for $\% \mathrm{C}, \mathrm{p}=0.007$ for $\% \mathrm{~N}$ ), with markedly reduced carbon and nitrogen contents in the collagen of non-adult domestic cattle. Analogous discrepancies were not observed for adult versus non-adult red deer, but this observation is based on a rather small number of individuals, especially for non-adult specimens $(n=4)$. The differences in $\mathrm{C}$ and $\mathrm{N}$ content between layers, highly significant when considering all species and age groups (KW, $\mathrm{p}<0.0001$ for $\% \mathrm{C}$ and $\% \mathrm{~N})$, remain significant when adult animals $(\mathrm{KW}, \mathrm{p}=0.001$ for $\% \mathrm{C}$, $\mathrm{p}=0.005$ for $\% \mathrm{~N})$ or non-adult animals $(\mathrm{KW}, \mathrm{p}=0.011$ for $\% \mathrm{C}, \mathrm{p}=0.015$ for $\% \mathrm{~N})$ are taken into account separately.

The $\delta^{13} \mathrm{C}$ values for domestic cattle ranged from $-25.6 \%$ to $-21.1 \%$ o $(-22.3 \%$ o $\pm 0.85, \mathrm{n}=53)$, with a narrow range for adult animals $(-22.8 \%$ to $-21.6 \%$; $-22.1 \%$ $\pm 0.35, \mathrm{n}=31)$. Red deer samples displayed carbon isotope values between $-25.0 \%$ and $-22.1 \% 0(-23.4 \% 0 \pm 0.78, \mathrm{n}=20)$. Differences in $\delta^{13} \mathrm{C}$ values between all domestic cattle and red deer were highly significant (MW, p<0.0001), while there were no significant differences observed between adult and non-adult animals on an intra-species level. $\mathrm{C}$ isotope data of all domestic cattle are similar within Layers 1 and 2, but rather variable when Layers 1 and 6/5 or Layers 2 and 6/5 are compared, although differences are not significant. In contrast, $\delta^{13} \mathrm{C}$ values of all red deer are 
quite similar for Layers 2 and 6/5, but are significantly different between Layers 1 and 6/5 (MW, p=0.008) and between Layers 1 and 2 (MW, p=0.004).

The results of the $\delta^{13} \mathrm{C}$ analyses are displayed in Figure 5. There is a considerable overlap between the carbon isotope values of red deer and domestic cattle in Layer 1, whereas Layer 2 shows a very different picture, with a distinct separation and a marginal overlap of red deer and domestic cattle $\mathrm{C}$ isotopic values. The variance of the carbon isotope composition for domestic cattle in Layers $6 / 5$ is considerably larger and covers a range of almost 5\%. Interestingly, two non-adult domestic cattle show $\delta^{13} \mathrm{C}$ values that are lower than those of red deer. The distinction between red deer and domestic cattle is obvious but not as clear as in Layer 2. Four young domestic cattle, between one and 18 months of age, exhibit $\delta^{13} \mathrm{C}$ values that correspond to the red deer's $\mathrm{C}$ isotope range. One adult red deer yielded a very low $\delta^{13} \mathrm{C}$ value, similar to the outlier values of domestic cattle. Apart from that, the values of red deer of the Layers $6 / 5$ and 2 are rather similar. The carbon isotope values of adult versus non-adult herbivores clearly overlap within all layers, indicating that in general, no obvious differences exist between age groups, i.e. no obvious patterns in $\delta^{13} \mathrm{C}$ values related to the age of the nonadult domestic cattle could be discerned (Figure 6).

\section{Discussion}

\subsection{The application of stable carbon isotope analysis to wetland archeological sites}

A regularly abandoned and reoccupied settlement site allows insights into changes of environmental conditions and domestic animal husbandry strategies over time in a specific region. In this respect, wetland archeological sites are a valuable source of information because the accurately dated stratigraphic evidence, together with well-preserved archeological material, permits diachronic observations. Animal bones are often preserved in large quantities, providing insight into subsistence and livestock management strategies. We know that domestic and wild animals played essential roles throughout the periods discussed here (Schibler, 2006). The application of stable carbon isotope analysis on faunal remains helps to understand prehistoric economic strategies in greater detail. There are only few carbon isotope data for prehistoric wetland sites, however. C isotope measurements from red deer dentin samples from the Horgen period lakeshore settlement Zug-Riedmatt (around 3250 and $3150 \mathrm{BC}$ ) in Central Switzerland (Schumpf, 2013) revealed $\delta^{13} \mathrm{C}$ values between $-25.5 \%$ and $-22.5 \%$, indicative of a rather dense woodland environment around Lake Zug. Moreover, differential $\delta^{13} \mathrm{C}$ values for collagen samples from red deer (-22.4\%o) versus domestic cattle ($21.5 \%$ o to $-20.5 \%$ ) from the wetland site Reute-Schorrenried $\left(38^{\text {th }}\right.$ century BC) in southern 
Germany, has been taken as putative evidence for grazing in different habitats; that is, dense forest (red deer) on the one hand and open landscape (domestic cattle) on the other (Drucker and Bocherens, 2010). Similar observations enabling the differentiation between open grassland cattle grazing on the one hand and red deer forest browsing on the other were made by Noe-Nygaard and colleagues (2005), who compared $\delta^{13} \mathrm{C}$ and $\delta^{15} \mathrm{~N}$ values of Holocene aurochs, cattle and red deer from settlement sites near lakes and bog deposits in southern Scandinavia. In analogy to these studies, we argue below that the marked differences in $\delta^{13} \mathrm{C}$ values in domestic cattle and red deer bone collagen from Zurich-Mozartstrasse indicate an opening of the landscape over time and reflect the different habitat proclivities of the two species, with domestic cattle occupying areas of more open vegetation. Our results for Layer 1, which show a clear overlapping between the $\delta^{13} \mathrm{C}$ values of red deer and domestic cattle, suggest that the differences in the bone collagen carbon isotopic compositions between red deer and domestic cattle in Layers $6 / 5$ and 2 are not related to metabolically differing fractionation processes. The absence of any trophic level shift related to suckling is indicated by the absence of significant differences in $\delta^{13} \mathrm{C}$ between non-adult and adult domestic cattle and red deer from all archeological layers. The lack of significant differences in collagen yield between layers, animal species and age groups confirms the good comparability of all our samples over time, and suggests that potential bias in $\delta^{13} \mathrm{C}$ due to effects of differential preservation can be excluded. The significant differences in $\mathrm{C} \%$ and $\mathrm{N} \%$ in collagen in Layers 6/5 compared to Layers 2 and 1 may be explained by a more advanced degradation of bone collagen in the older layers, although the criteria of good collagen preservation are met in all cases. The difference in $\mathrm{C} \%$ and $\mathrm{N} \%$ in bone collagen of domestic cattle might be related to a different ratio of non-adult to adult specimens, which is $15: 4$ in the older Layers 6/5, but only 7:27 in the younger Layers 2 and 1.

\subsection{Indications for a landscape opening based on red deer stable carbon isotope ratios}

Habitat changes over time are suggested by the carbon isotope shifts observed for red deer bone collagen between stratigraphic layers: mean $\delta^{13} \mathrm{C}$ values change from $-24.1 \pm 0.7 \%$ (Layers $6 / 5$ ) to $-22.5 \pm 0.3 \%$ (Layer 1 ). These values are comparatively low, indicating pasture grounds in a rather closed environment. Based on our dataset, values between -22.1\%o (Layer 1) and $-22.7 \%$ (Layer 2) can be regarded as threshold for differentiating between large herbivores feeding from open versus closed environments in a temperate deciduous ecosystem (Figure 5 and Table 1). These values are comparable to those reported in the studies of Drucker et al. $(2003 ; 2011)$ on herbivores in similar pre-industrial ecosystems. The generally 
low $\delta^{13} \mathrm{C}$ values observed for red deer, with maxima of $-23.5 \%$ or Layers $6 / 5,-22.7 \%$ o for Layer 2 and $-22.1 \%$ for Layer 1 , as well as the low inter-individual variability with $1.5 \%$, $1.7 \%$ and $0.7 \%$, respectively, underscore the interrelation between forested areas and these animals. The very low ${ }^{13} \mathrm{C} /{ }^{12} \mathrm{C}$ values of red deer in the Layers $6 / 5$ may reflect feeding grounds in a densely forested environment, which is in good agreement with red deer data from a modern primeval forest ecosystem in Poland/Belarus (National Park Bialowieza), as summarized in Bocherens and Drucker (2003). Links between increasing/decreasing $\delta^{13} \mathrm{C}$ trends and an opening/closure of the landscape were also observed in Western Europe during more ancient periods (Noe-Nygaard et al., 2005; Drucker and Bocherens, 2009).

Apart from the canopy effect, an increase in precipitation and humidity might cause more depleted $\delta^{13} \mathrm{C}$ values in the herbivore's feeding plants (Hedges et al., 2004; Kohn, 2010). Stevens et al. (2006) studied modern European red deer populations in various geographic environments. Excluding any detectable $\delta^{13} \mathrm{C}$ canopy effect, they suggested that the differences in the mean-population $\delta^{13} \mathrm{C}$ were related mainly to climatic factors. However, climatic variations cannot explain the differences seen between red deer and domestic cattle in our data set, given that the isotope ratios should be equally affected by changes in precipitation and humidity. Thus, we argue that our results indicate environmental changes, i.e. the existence of a dense forest in the early $4^{\text {th }}$ millennium BC and an opening of the landscape during the $3^{\text {rd }}$ millennium BC. Based on our data, it seems plausible that the red deer habitat underwent significant changes between the $27^{\text {th }}$ and the $20^{\text {th }}$ century $\mathrm{BC}$. This proposed habitat shift is clearly supported by observations of archeobotanical and archeozoological studies in the Lake Zurich region that suggest floral and faunal community structure changes. For example, evidence exists for the intensified use of arable land with weeds such as creeping tormentil (Potentilla reptans) or white clover (Trifolium repens), and higher relative proportions of animals and birds preferring structured, rather open environments, e.g. red fox (Vulpes vulpes), brown hare (Lepus europaeus) or carrion crow (Corvus corone). Additional indirect indication for environmental change (i.e. deforestation and opening of the landscape) at that time is provided by the increased abundance of pike (Esox lucius) and carp fish (Cyprinidae), which can be related to the emergence of reed beds along lakeshores in response to the eutrophication through erosion of deforested soils (Jacomet et al., 1989; Schibler et al., 1997).

\subsection{Implications for herding strategies based on domestic cattle stable carbon isotope ratios}


In contrast to the observed red deer's $\mathrm{C}$ isotope shift, the shift in mean $\delta^{13} \mathrm{C}$ values for domestic cattle bone collagen from $-22.7 \pm 1.3 \%$ (Layers 6/5) to $-22.1 \pm 0.3 \%$ o (Layer 1) was not significant. This is not surprising, given that open environments are supposed to be the prime habitat of domestic cattle. The lowest $\delta^{13} \mathrm{C}$ values clustered around $-22.7 \%$ or fayers 2 and 1, respectively, with narrow inter-individual variations (1.3\%o for Layer 2 and $1.1 \%$ for Layer 1), suggesting the use of unforested areas. Given that in essentially all layers, single values are relatively low, it seems probable that some domestic cattle fed from a mixture of resources from both forest habitat and open environments. The very low $\delta^{13} \mathrm{C}$ values of some non-adult domestic cattle in Layers $6 / 5$ are of special interest. The inter-individual variation in these layers is quite extensive (4.6\%), at least when both non-adult and adult animals are considered (while it is $1.1 \%$ for the four adults only). This variance is clearly larger than the inter-individual range observed in modern large herbivores from a boreal forest environment (Central Saskatchewan, Canada), which did not exceed 3.1\%o within a given population (Drucker et al., 2008). Even though this observation is based on bison (which are also bovines), we suggest that the large intra-species variance of domestic cattle in the oldest layers from Zurich-Mozartstrasse is related to human intervention in livestock management, i.e. variation in grazing environments in a temperate deciduous forest or in foddering techniques.

Schnyder et al. (2006) looked at the influence of humidity on the variability of $\delta^{13} \mathrm{C}$ in modern cattle grazing on temperate humid grassland. They concluded that variable site conditions (soil moisture) but also interannual variation of weather can affect the carbon isotope values of vegetation and consequently animal tissues, with more negative $\delta^{13} \mathrm{C}$ values for grazing in humid areas. We will not be able to assess interannual weather variation, but it is reasonable to assume that grazing in open but wet environments such as riverside woodlands and river deltas (e.g. the Sihldelta in close vicinity to Zurich-Mozartstrasse) would result in low $\delta^{13} \mathrm{C}$ values of domestic cattle bone collagen samples. Several authors outlined that domestic cattle management and feeding practices were highly elaborated, and seasonally differing strategies are likely (Schibler et al., 1997; Ebersbach, 2002; Kühn et al., 2013). One of these strategies to consider is leaf foddering in winter. That is, mainly young animals were kept in, or at least near, the settlement during winter times and fed by humans, who gathered low- $\delta^{13} \mathrm{C}$ plants or harvested leaves and twigs from dense woodland and possibly from riverside woodlands and river deltas. Winter leaf foddering may thus result in very low $\delta^{13} \mathrm{C}$ values in cattle bone collagen, as already suggested for Bercy, a Neolithic dryland settlement in the Paris Basin, France (Balasse et al., 2012). However, the isotope effect of winter leaf foddering may not 
always be that pronounced and it simply depends on the $\delta^{13} \mathrm{C}$ of the fodder and thus the harvest time. For example, winter leaf foddering as a potential feeding strategy of domestic cattle in southern Scandinavia was discussed in line of the elm decline at the AtlanticSubboreal transition (Noe-Nygaard et al., 2005), where the authors did not see any indications of leaf foddering on the basis of their isotopic data set. Irrespective of the potential of $\mathrm{C}$ isotopic measurements to gain constraints on winter leaf foddering, dung analyses can provide independent evidence for such feeding strategies, as has been shown for small and large ruminants at several wetland sites in Switzerland (Kühn et al., 2013). One example is the settlement Wetzikon-Robenhausen, canton Zurich, another one is Thayngen-Weier II, canton Schaffhausen, where some of the excavated buildings have been interpreted as stables, although this is a matter of debate (Ebersbach, 2002). All of them are dated to the early $4^{\text {th }}$ millennium BC and are chronologically comparable to the Layers 6/5 of ZurichMozartstrasse. Hence, the low $\delta^{13} \mathrm{C}$ values in these layers may be indeed explained by winter leaf foddering. However, other explanations for low carbon isotope values, such as woodland pasturing of domestic cattle, cannot be ruled out completely, especially for seasons other than winter. Woodland pasturing was a common land management system in historical times in Europe even though large grazing grounds were available (Ebersbach, 2002). Such grounds can certainly be regarded as one of the preconditions for increased cattle breeding efforts in the Neolithic (Schibler and Jacomet, 1999; Ebersbach, 2002), which is suggested for 2800 BC (Corded Ware period) onwards in the Lake Zurich area (Schibler et al., 1997). The association of relatively high $\delta^{13} \mathrm{C}$ values and (man-made) open grazing grounds was postulated for other European regions and time periods (e.g. Noe-Nygaard et al., 2005; Drucker and Bocherens, 2009; Sommer et al., 2011). The high $\delta^{13} \mathrm{C}$ values of domestic cattle compared to red deer in our study emphasize the importance and availability of open landscapes throughout the complete stratigraphic sequence of the settlement from the early $40^{\text {th }}$ century BC onwards. We argue that domestic cattle management was always linked to specific niche use (Stewart et al., 2003) and seasonal herding strategies. Ongoing multi-isotope (strontium, oxygen, carbon, nitrogen) analyses on tooth enamel and dentin of the sampled individuals will shed light on seasonally varying feeding practices and herding strategies in the Lake Zurich region. Overall, it needs to be stressed that livestock management was certainly influenced strongly by cultural, social and individual human decisions. It is very likely that extensive land-use and diversified herding and feeding management increased the resilience of Neolithic farming communities (Doppler et al., 2012; 2013), factors that may have played key roles in opening the landscape and in changing cattle herding strategies over time. 


\section{Summary and conclusions}

The wetland site of Zurich-Mozartstrasse, with its extensive stratigraphy and precisely dated settlement layers, offers a unique opportunity to observe diachronic changes in land-use and animal management at a local and regional scale. Our isotopic data set is one of the first of its kind for Swiss wetland sites, and one of the few applied to lakeshore settlements in general. We analyzed the carbon isotope composition of domestic cattle and red deer bone collagen, and observed shifts in the $\delta^{13} \mathrm{C}$ between the early $4^{\text {th }}$ millennium and the $2^{\text {nd }}$ millennium $\mathrm{BC}$. Trophic level shifts, suckling effects and metabolically differing fractionation processes can be excluded as explanations for differences in carbon isotope ratios between red deer and domestic cattle, and between different age groups. We rather suggest that the significant difference between the carbon isotope values of red deer versus domestic cattle points to different habitat use by these species, with cattle mainly grazing in open grasslands and red deer feeding in more closed woodlands. The increasing $\delta^{13} \mathrm{C}$ trend of red deer over time is best explained by an opening of the landscape, and can be related to a reduction in the canopy effect. Our interpretation emphasizes the potential of stable carbon isotope measurements of herbivore bone collagen for tracking forest cover. This is consistent with archeobotanical and archeozoological data suggesting the existence of an opened landscape from $2800 \mathrm{BC}$ onwards. In addition, we argue that relatively high $\delta^{13} \mathrm{C}$ values for domestic cattle observed throughout the stratigraphic sequence of the study site indicate the importance and availability of pastures in open environments as early as the $40^{\text {th }}$ century $\mathrm{BC}$. The low $\delta^{13} \mathrm{C}$ values of several non-adult cattle in the early $4^{\text {th }}$ millennium BC imply a greater variety of animal management strategies compared to the younger periods, potentially linked to differing herding skills, specific niche use and leaf foddering. These conclusions underline the importance of carbon isotope analyses of collagen from domestic cattle and red deer bones in order to explore paleoenvironmental conditions and human-induced subsistence strategies, which certainly contributed to changes in forest cover over time.

\section{Acknowledgments}

We thank the Swiss National Science Foundation for funding our project (CR12I2_143815/1) 'Isotope analysis of well dated cattle and red deer bones from Swiss Neolithic lakeshore settlements as indicator for herd management, dairying, environment and human impact' (see www.i-bone.ch). Our colleagues at the Archeological Services of canton Zurich, Beat Eberschweiler and Simon Vogt, and of canton Thurgau, Hansjörg Brem and Urs Leuzinger, 
are thanked for their collaboration and advice in sample acquisition. Age determination of the sampled animals was thankfully undertaken by Marguerita Schäfer, University of Basel. Sabine Deschler-Erb, Renate Ebersbach and Stefanie Jacomet, University of Basel, are thanked for their comments and advice. We give thanks to Mark Rollog, University of Adelaide, for some technical assistance with isotopic analysis. We would like to thank Dorothée Drucker and an anonymous reviewer for their valuable comments, which substantially improved this paper.

\section{References}

Ambrose, S.H., 1990. Preparation and characterization of bone and tooth collagen for isotopic analysis. Journal of Archaeological Science 17, 431-451.

Balasse, M., Boury, L., Ughetto-Monfrin, J., Tresset, A., 2012. Stable isotope insights $\left(\delta^{18} \mathrm{O}\right.$, $\delta^{13} \mathrm{C}$ ) into cattle and sheep husbandry at Bercy (Paris, France, $4^{\text {th }}$ millennium BC): birth seasonality and winter leaf foddering. Environmental Archaeology 17 (1), 29-44.

Billamboz, A., 2012. Les villages néolithiques de la baie de Sipplingen sur le lac de Constance: rythmes de l'occupation dans le contexte de l'économie forestière. In: Honegger, M., Mordant, C. (Eds.), L'homme au bord de l'eau. Archéologie des zones littorales du Néolithique à la Protohistoire. Cahiers d'archéologie romande 132. Cahiers d'archéologie romande, Lausanne et Paris, pp. 299-314.

Blaise, E., 2009. Économie animale et gestion des troupeaux au Néolithique final en Provence. Approche archéozoologique et contribution des analyses isotopiques de l'émail dentaire. PhD thesis, Université Aix-Marseille I, Aix-en-Provence.

Bleicher, N., 2009. Altes Holz in neuem Licht. Archäologische und dendrochronologische Untersuchungen an spätneolithischen Feuchtbodensiedlungen in Oberschwaben. Berichte zu Ufer- und Moorsiedlungen Südwestdeutschlands V. Konrad Theiss, Stuttgart.

Bleicher, N., 2011. Absolutdatierung. In: Schmidheiny, M., Zürich «Mozartstrasse». Neolithische und bronzezeitliche Ufersiedlungen, Band 4: Die frühbronzezeitliche Besiedlung. Monographien der Kantonsarchäologie Zürich 42. Fotorotar, Zürich und Egg, pp. 49-67. 
Bleuer, E., Hardmeyer, B., 1993. Zürich «Mozartstrasse». Neolithische und bronzezeitliche Ufersiedlungen, Band 3: Die neolithische Keramik. Zürcher Denkmalpflege, Archäologische Monographien 18. Fotorotar, Egg und Zürich.

Bocherens, H., Drucker, D., 2003. Trophic level isotopic enrichments for carbon and nitrogen in collagen: case studies from recent and ancient terrestrial ecosystems, International Journal of Osteoarchaeology 13, 46-53.

Bonafini, M., Pellegrini, M., Ditchfield, P., Pollard, A.M., 2013. Investigation of the 'canopy effect' in the isotope ecology of temperate Woodlands. Journal of Archaeological Science 40, 3926-3935.

Cerling, T.E., Manthi, F.K., Mbua, E.N., Leakey, L.N., Leakey, M.G., Leakey, R.E., Brown, F.H., Grine, F.E., Hart, J.A., Kaleme, P., Roche, H., Uno, K.T., Wood, B.A., 2013. Stable isotope-based diet reconstructions of Turkana Basin hominins. Proceedings of the National Academy of Sciences 110 (26), 10501-10506.

Chiquet, P., 2012. La faune du Néolithique moyen. Analyse des modes d'exploitation des ressources animals et contribution à l'interprétation de l'espace villageois. Cahiers d'archéologie romande 131. Cahiers d'archéologie romande, Lausanne.

Clarke, C., 2013. Palaeoecological Reconstructions. In: Menotti, F., O’Sullivan, A. (Eds.), The Oxford Handbook of Wetland Archaeology. Oxford University Press, Oxford, pp. 539554.

Denaire, A., Doppler, T., Nicod, P.-Y., van Willigen, S., 2011. Espaces culturels, frontières et

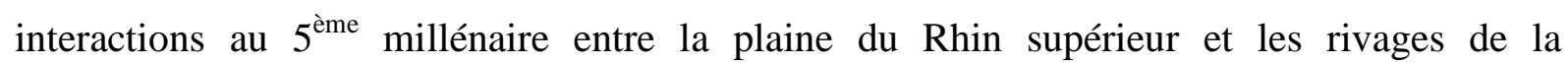
Méditerranée. Jahrbuch Archäologie Schweiz 94, 21-59.

DeNiro, M.J., 1985. Postmortem preservation and alteration of in vivo bone collagen isotope ratios in relation to palaeodietary reconstruction. Nature 317, 806-809. 
Deschler-Erb, S., Marti-Grädel, E., 2004. Viehhaltung und Jagd. Ergebnisse der Untersuchung der handaufgelesenen Tierknochen. In: Jacomet, S., Leuzinger, U., Schibler, J. (Eds.), Die jungsteinzeitliche Seeufersiedlung Arbon Bleiche 3. Umwelt und Wirtschaft. Archäologie im Thurgau 12. Departement für Erziehung und Kultur des Kantons Thurgau, Frauenfeld, pp. 158-252.

Doppler, T., Pichler, S., Röder, B., Schibler, J., 2012. All in good tradition? Some thoughts on cultural markers in a Late Neolithic lakeside dwelling from Switzerland. In: Midgley, M.S., Sanders, J. (Eds.), Lake Dwellings after Robert Munro. Sidestone Press, Leiden, pp. 93-112.

Doppler, T., Pichler, S., Röder, B., Schibler, J., 2013. Coping with crises I: Subsistence variety and resilience in the Late Neolithic lakeshore settlement Arbon Bleiche 3 (Switzerland). In: Kerig, T., Zimmermann, A. (Eds.), Economic archaeology: from structure to performance in European archaeology. Universitätsforschungen zur Prähistorischen Archäologie 237. Habelt, Bonn, pp. 163-174.

Drucker, D.G., Bocherens, H., 2009. Carbon stable isotopes of mammal bones as tracers of canopy development and habitat use in temperate and boreal contexts. In: Creighton, J.D., Roney, P.J. (Eds.), Forest canopies: Forest production, ecosystem health, and climate conditions. Nova Science Publishers, New York, pp. 103-109.

Drucker, D., Bocherens, H., 2010. Analyses isotopiques du carbone $\left({ }^{13} \mathrm{C}\right)$ du collagène des restes de faune de Reute-Schorrenried. Fundberichte aus Baden-Württemberg 31, 89-95.

Drucker, D., Bocherens, H., Bridault, A., Billiou, D., 2003. Carbon and nitrogen isotopic composition of Red Deer (Cervus elaphus) collagen as a tool for tracking palaeoenvironmental change during Lateglacial and Early Holocene in northern Jura (France). Palaeogeography, Palaeoclimatology, Palaeoecology 195, 375-388.

Drucker, D.G., Bridault, A., Hobson, K.A., Szuma, E., Bocherens, H., 2008. Can carbon-13 in large herbivores reflect the canopy effect in temperate and boreal ecosystems? Evidence from modern and ancient ungulates. Palaeogeography, Palaeoclimatology, Palaeoecology 266, 6982. 
Drucker, D.G., Bridault, A., Cupillard, C., Hujic, A., Bocherens, H., 2011. Evolution of habitat and environment of red deer (Cervus elaphus) during the Late-glacial and early Holocene in eastern France (French Jura and the western Alps) using multi-isotope analysis $\left(\delta^{13} \mathrm{C}, \delta^{15} \mathrm{~N}, \delta^{18} \mathrm{O}, \delta^{34} \mathrm{~S}\right)$ of archaeological remains. Quaternary International 245, 268-278.

Ducos, P., 1968. L'origine des animaux domestiques en Palestine. Publications de l'Institut de Préhistoire de l'université de Bordeaux, Bordeaux.

Ebersbach, R., 2002. Von Bauern und Rindern. Eine Ökosystemanalyse zur Bedeutung der Rinderhaltung in bäuerlichen Gesellschaften als Grundlage zur Modellbildung im Neolithikum. Basler Beiträge zur Archäologie 15. Schwabe, Basel.

Ebersbach, R., 2013. Houses, households, and settlements. Architecture and Living Spaces. In: Menotti, F., O'Sullivan, A. (Eds.), The Oxford Handbook of Wetland Archaeology. Oxford University Press, Oxford, pp. 283-301.

Ebersbach, R., Ruckstuhl, B., Bleicher, N., 2015. Zürich «Mozartstrasse». Neolithische und bronzezeitliche Ufersiedlungen, Band 5: Die neolithischen Befunde und die Dendroarchäologie. Monographien der Kantonsarchäologie Zürich 47. Fotorotar, Zürich und Egg.

Fischer, A., Olsen, J., Richards, M., Heinemeier, J., Sveinbjörnsdóttir, A.E., Bennike, P., 2007. Coast-inland mobility and diet in the Danish Mesolithic and Neolithic: evidence from stable isotope values of humans and dogs. Journal of Archaeological Science 34, 2125-2150.

Gąsiorowski, M., Hercman, H., Ridush, B., Stefaniak, K., 2014. Environment and climate of the Crimean Mountains during the Late Pleistocene inferred from stable isotope analysis of red deer (Cervus elaphus) bones from the Emine-Bair-Khosar Cave. Quaternary International 326-327, 243-249.

Gillis, R., 2012. Osteological and isotopic contributions to the study of dairy husbandry during the European Neolithic. PhD thesis, Muséum national d'histoire naturelle, Paris. 
Grant, A., 1982. The use of tooth wear as a guide to the age of domestic ungulates. In: Wilson, B., Grigson, C., Payne, S. (Eds.), Ageing and sexing animal bones from archaeological sites. British Archaeological Reports, British Series 109. Oxford University Press, Oxford, pp. 91-108.

Gross, E., Brombacher, C., Dick, M., Diggelmann, K., Hardmeyer, B., Jagher, R., Ritzmann, C., Ruckstuhl, B., Ruoff, U., Schibler, J., Vaughan, P.C., Wyprächtiger, K., 1987. Zürich «Mozartstrasse». Neolithische und bronzezeitliche Ufersiedlungen, Band 1. Berichte der Zürcher Denkmalpflege, Monographien 4. Orell Füssli, Zürich.

Gross, E., Bleuer, E., Hardmeyer, B., Rast-Eicher, A., Ritzmann, C., Ruckstuhl, B., Ruoff, U., Schibler, J., 1992. Zürich «Mozartstrasse». Neolithische und bronzezeitliche Ufersiedlungen, Band 2: Tafeln. Berichte der Zürcher Denkmalpflege, Monografien 17. Fotorotar, Egg/Zürich.

Habermehl, K.-H., 1975. Altersbestimmung bei Haus- und Labortieren. Parey, Berlin.

Habermehl, K.-H., 1985. Altersbestimmung bei Wild- und Pelztieren. Parey, Hamburg.

Hafner, A., 1993. Lattrigen VI Riedstation. Siedlungsplan und Baugeschichte eines neolithischen Dorfes. Ufersiedlungen am Bielersee 4. Paul Haupt, Bern.

Hafner, A., Suter, P.J., 2005. Neolithikum: Raum / Zeit-Ordnung und neue Denkmodelle. Archäologie im Kanton Bern 6, 431-498.

Hedges, R.E.M., Stevens, R.E., Richards, M.P., 2004. Bone as a stable isotope archive for local climatic information. Quaternary Science Reviews 23, 959-965.

Hüster-Plogmann, H., Schibler, J., 1997. Archäozoologie. In: Schibler, J., Hüster Plogmann, H., Jacomet, S., Brombacher, C., Gross-Klee, E., Rast-Eicher, A., Ökonomie und Ökologie neolithischer und bronzezeitlicher Ufersiedlungen am Zürichsee. Monographien der Kantonsarchäologie Zürich 20. Fotorotar, Zürich und Egg, pp. 40-121. 
Hüster-Plogmann, H., Schibler, J., Jacomet, S., 1999. The significance of aurochs as hunted animal in the Swiss Neolithic. In: Weniger, G.-C. (Ed.), Archaeology and Biology of the Aurochs. Neanderthal-Museum, Mettmann, pp. 151-160.

IPAS, Altersbestimmung. http://ipna.unibas.ch/archbiol/methodik/index.html (05.08.2015).

Jacomet, S., Brombacher, C., Dick, M., 1989. Summary. In: Jacomet, S., Brombacher, C., Dick, M., Archäobotanik am Zürichsee. Ackerbau, Sammelwirtschaft und Umwelt von neolithischen und bronzezeitlichen Seeufersiedlungen im Raum Zürich. Berichte der Zürcher Denkmalpflege, Monographien 7. Orell Füssli, Zürich, pp. 243-245.

Jacomet, S., Leuzinger, U., Schibler, J., 2004. Synthesis. In: Jacomet, S., Leuzinger, U., Schibler, J. (Eds.), Die jungsteinzeitliche Seeufersiedlung Arbon Bleiche 3. Umwelt und Wirtschaft. Archäologie im Thurgau 12. Departement für Erziehung und Kultur des Kantons Thurgau, Frauenfeld, pp. 379-416.

Jørkov, M.L.S., Heinemeier, J., Lynnerup, N., 2007. Evaluating bone collagen extraction methods for stable isotope analysis in dietary studies. Journal of Archaeological Science 34, 1824-1829.

Kohn, M.J., 2010. Carbon isotope compositions of terrestrial C3 plants as indicators of (paleo)ecology and (paleo)climate. Proceedings of the National Academy of Sciences 107, 19691-19695.

Kühn, M., Maier, U., Herbig, C., Ismail-Meyer, K., Le Bailly, M., Wick, L., 2013. Methods for the examination of cattle, sheep and goat dung in prehistoric wetland settlements with examples of the sites Alleshausen-Täschenwiesen and Alleshausen-Grundwiesen (around cal 2900 BC) at Lake Federsee, south-west Germany. Journal of Environmental Archaeology 18 (1), 43-57.

Leuzinger, U., 2000. Die jungsteinzeitliche Seeufersiedlung Arbon Bleiche 3. Befunde. Archäologie im Thurgau 9. Departement für Erziehung und Kultur des Kantons Thurgau, Frauenfeld. 
Noe-Nygaard, N., Price, T.D., Hede, S.U., 2005. Diet of aurochs and early cattle in southern Scandinavia: evidence from ${ }^{15} \mathrm{~N}$ and ${ }^{13} \mathrm{C}$ stable isotopes. Journal of Archaeological Science $32,855-871$.

Longin, R., 1971. New method of collagen extraction for radiocarbon dating. Nature 230, 241-242.

Menotti, F. (Ed.), 2004. Living on the lake in prehistoric Europe.150 years of lake-dwelling research. Routledge, London.

Menotti, F., 2012. Wetland Archaeology and Beyond. Theory and Practice. Oxford University Press, Oxford.

Menotti, F., O’Sullivan, A. (Eds.), 2013. The Oxford Handbook of Wetland Archaeology. Oxford University Press, Oxford.

Oelze, V.M., Siebert, A., Nicklisch, N., Meller, H., Dresely, V., Alt, K.W., 2011. Early Neolithic diet and animal husbandry: stable isotope evidence from three Linearbandkeramik (LBK) sites in Central Germany. Journal of Archaeological Science 38, 270-279.

Richards, M., Fuller, B.T., Molleson, T.I., 2006. Stable isotope palaeodietary study of humans and fauna from the multi-period (Iron Age, Viking and Late Medieval) site of Newark Bay, Orkney. Journal of Archaeological Science 33, 122-131.

Riglet, P.-H., 1977. Contributions à l'étude de l'âge du cerf elaphe (Cervus elaphus L.). École Nationale Vétérinaire d'Alfort, Maisons-Alfort.

Rychner, V., 1998. Chronologie. In: Hochuli, S., Niffeler, U., Rychner, V. (Eds.), Die Schweiz vom Paläolithikum bis zum frühen Mittelalter - SPM III: Bronzezeit. Schweizerische Gesellschaft für Ur- und Frühgeschichte, Basel, pp. 13-19.

Schibler, J., 1997. Haus- und Wildtiernutzung in den jungsteinzeitlichen Feuchtbodensiedlungen des Kantons Thurgau. Archäologie der Schweiz 20 (2), 57-61. 
Schibler, J., 2006. The economy and environment of the 4th and 3rd millennia BC in the northern Alpine foreland based on studies of animal bones. Environmental Archaeology 11 (1), 49-64.

Schibler, J., Jacomet, S., 1999. Archaeozoological and archaeobotanical evidence of human impact on Neolithic environments in Switzerland. In: Benecke, N. (Ed.), The Holocene history of the European vertebrate fauna - Modern aspects of research. Archäologie in Eurasien 6. Verlag Marie Leidorf, Rahden/Westf., pp. 339-354.

Schibler, J., Jacomet, S., Hüster-Plogmann, H., Brombacher, C., 1997. Synthesis. In: Schibler, J., Hüster Plogmann, H., Jacomet, S., Brombacher, C., Gross-Klee, E., Rast-Eicher, A., Ökonomie und Ökologie neolithischer und bronzezeitlicher Ufersiedlungen am Zürichsee. Monographien der Kantonsarchäologie Zürich 20. Fotorotar, Zürich und Egg, pp. 329-361.

Schlichtherle, H., Vogt, R., Maier, U., Herbig, C., Schmidt, E., Ismail-Meyer, K., Kühn, M., Wick, L., Dufraisse, A., 2011. Die endneolithische Moorsiedlung Bad Buchau-Torwiesen II am Federsee. Band 1: Naturwissenschaftliche Untersuchungen. Hemmenhofener Skripte 9. Janus-Verlag, Freiburg i. Br.

Schmidheiny, M., 2011. Zürich «Mozartstrasse». Neolithische und bronzezeitliche Ufersiedlungen, Band 4: Die frühbronzezeitliche Besiedlung. Monographien der Kantonsarchäologie Zürich 42. Fotorotar, Zürich und Egg.

Schnyder, H., Schwertl, M., Auerswald, K., Schäufele, R., 2006. Hair of grazing cattle provides an integrated measure of the effects of site conditions and interannual weather variability on $\delta^{13} \mathrm{C}$ of temperate humid grassland. Global Change Biology 12, 1315-1329.

Schumpf, E., 2013. Die Analyse stabiler Isotope $\left(\delta^{18} \mathrm{O}, \delta^{13} \mathrm{C}, \delta^{15} \mathrm{~N}\right)$ an Schmelz und Dentin von Hirschzähnen aus der horgenzeitlichen Seeufersiedlung Zug-Riedmatt. Unterschiedliche Jagdgebiete im Laufe der Besiedlung aufgrund wechselnder klimatischer Bedingungen? Unpublished master thesis, Institute of Prehistory and Archaeological Science, University of Basel, Basel. 
Sealy, J., Johnson, M., Richards, M., Nehlich, O., 2014. Comparison of two methods of extracting bone collagen for stable carbon and nitrogen isotope analysis: comparing whole bone demineralization with gelatinization and ultrafiltration. Journal of Archaeological Science 47, 64-69.

Sommer, R.S., Benecke, N., Lõugas, L., Nelle, O., Schmölcke, U., 2011. Holocene survival of the wild horse in Europe: a matter of open landscape? Journal of Quaternary Science 26 (8), 805-812.

Stevens, R.E., Lister, A.M., Hedges R.E.M., 2006. Predicting diet, trophic level and palaeoecology from bone stable isotope analysis: a comparative study of five red deer populations. Oecologia 149, 12-21.

Stevens, R. E., Hermoso-Buxán, X. L., Marín-Arroyo, A. B., González-Morales, M. R., Straus, L. G., 2014. Investigation of Late Pleistocene and Early Holocene palaeoenvironmental change at El Mirón cave (Cantabria, Spain): Insights from carbon and nitrogen isotope analyses of red deer. Palaeogeography, Palaeoclimatology, Palaeoecology $414,46-60$.

Stewart, K.M., Bowyer, R.T., Kie, J.G., Dick, B.L., Ben-David, M., 2003. Niche partitioning among mule deer, elk, and cattle: do stable isotopes reflect dietary niche? Ecoscience 10, 297302.

Stöckli, W.E., 2009. Chronologie und Regionalität des jüngeren Neolithikums (4300-2400 v.Chr.) im Schweizer Mittelland, in Süddeutschland und in Ostfrankreich. Antiqua 45. Archäologie Schweiz, Basel.

van der Merwe, N.J., Medina, E., 1991. The canopy effect, carbon isotope ratios and foodwebs in Amazonia. Journal of Archaeological Science 18, 249-259.

van Klinken, G.J., 1999. Bone collagen quality indicators for palaeodietary and radiocarbon measurements. Journal of Archaeological Science 26, 687-695.

Vogel, J.C., 1978. Recycling of $\mathrm{CO}_{2}$ in a forest environment. Oecologia Plantarum 13, 89-94.

von Raesfeld, F., Reulecke, K., 1988. Das Rotwild. Naturgeschichte, Hege, Jagdausübung. Parey, Hamburg. 


\section{Figure 1}

Location of Zurich-Mozartstrasse at the northern end of Lake Zurich in Switzerland.

\section{Figure 2}

Stratigraphic sequence of Zurich-Mozartstrasse with vertical wooden post remains visible in the profile. The numbered dark layers represent the settlement occupations while the white layers (lake marl) indicate phases of abandonment during lake transgressions. Each archeological layer differs in thickness within the excavated area. Photograph: Gross et al. 1987, supplemented.

\section{Figure 3}

Chronological scheme for the Neolithic and Bronze Age in Central Switzerland. Simplified after Rychner (1998), Hafner and Suter (2005), Stöckli (2009) and Denaire et al. (2011). Very little is known about the beginning and the end of the Early and the Middle Neolithic. The given numbers are approximations. Additionally, the temporal placement of the sampled archeological layers is shown.

\section{Figure 4}

Significance of domestic and wild animals in Neolithic lakeshore settlements of Central Switzerland. The chronological development (columns) is based on find densities (number of bone fragments per square meter and settlement phase; see Schibler et al., 1997, 329). The relative proportions of domestic and wild animals in single time periods (lines) are given in percentages $(100 \%=$ number of all identifiable bone fragments). Graph: Schibler, 1997, modified.

\section{Figure 5}

Plot of $\delta^{13} \mathrm{C}$ values of cattle and red deer bone collagen versus stratigraphic layers.

\section{Figure 6}

Plot of $\delta^{13} \mathrm{C}$ values of cattle bone collagen according to age categories following IPAS (Altersbestimmung) versus stratigraphic layers. Non-adult and adult cattle are shown on different levels.

\section{Table 1}

Cattle and red deer samples with information on the stratigraphic layer, individual data on skeletal element, age ( $y=$ years, $m=$ months), age group and results of isotopic measurements of bone collagen (mean of duplicate measurements for each sample).

\section{Table 2}

Tested differences in $\delta^{13} \mathrm{C}$ values using Mann-Whitney statistics $(\alpha=0.05)$. 


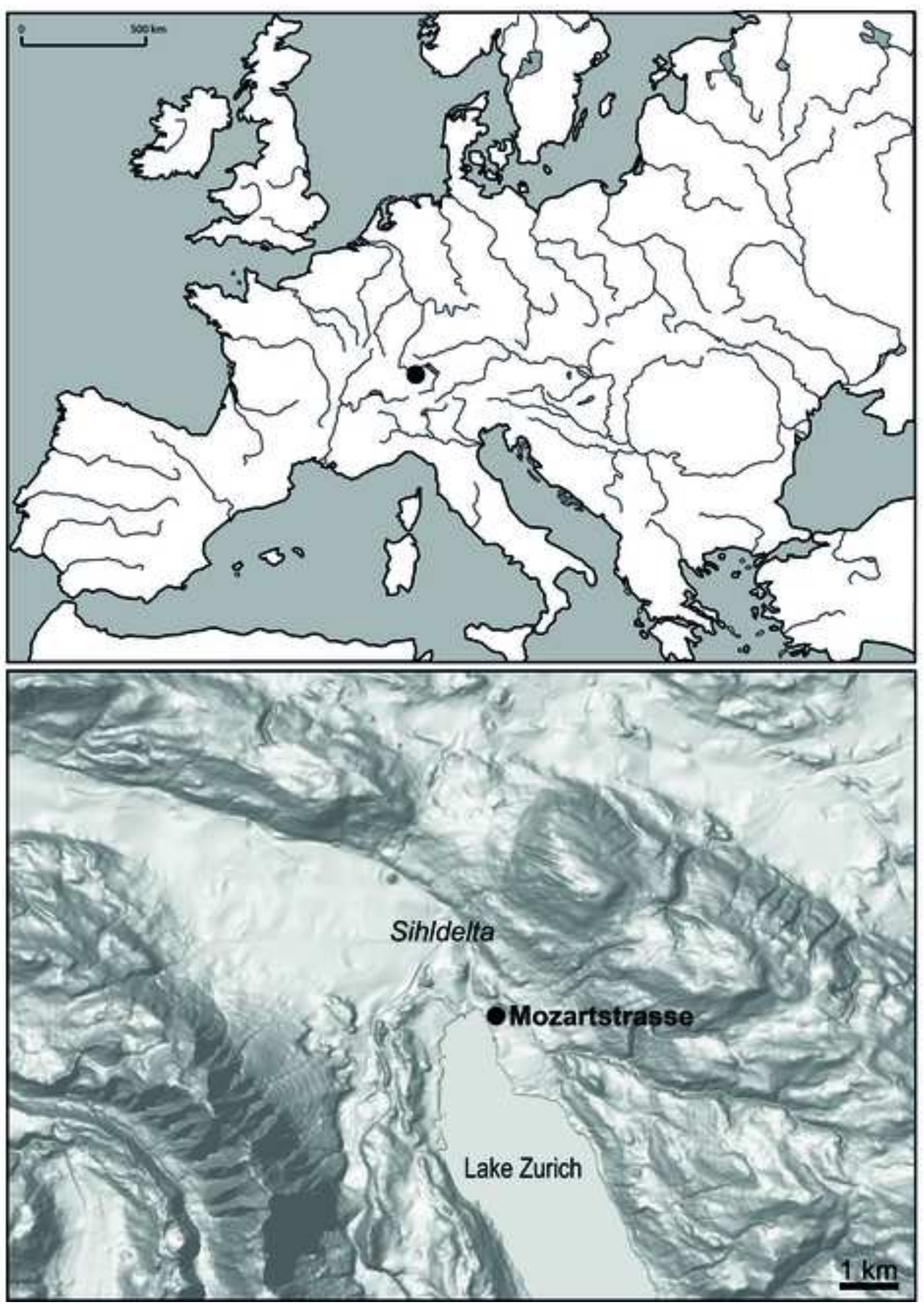




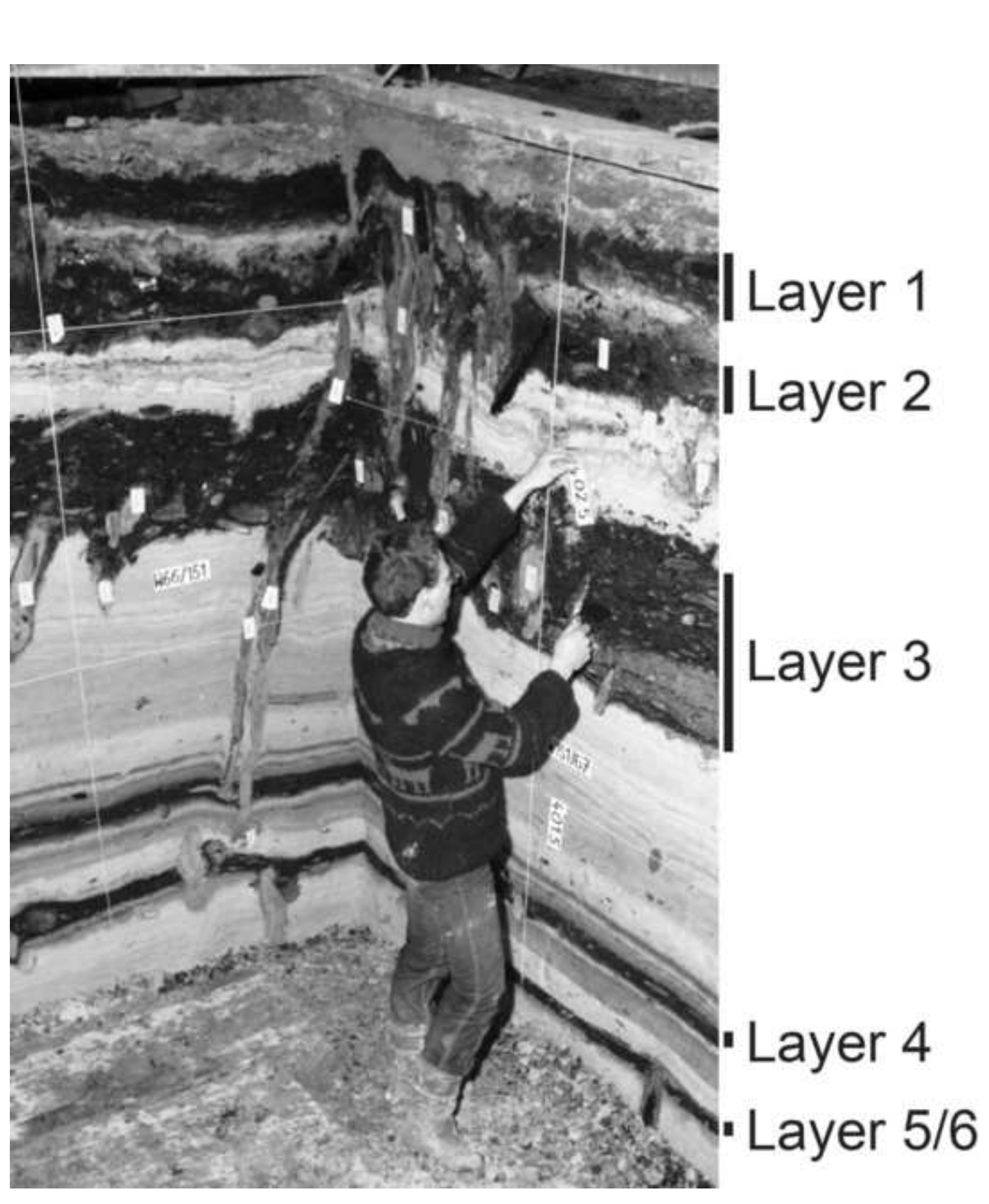

Figure 2
(n)

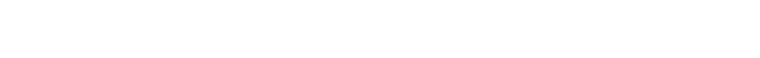




\section{BC Periods}

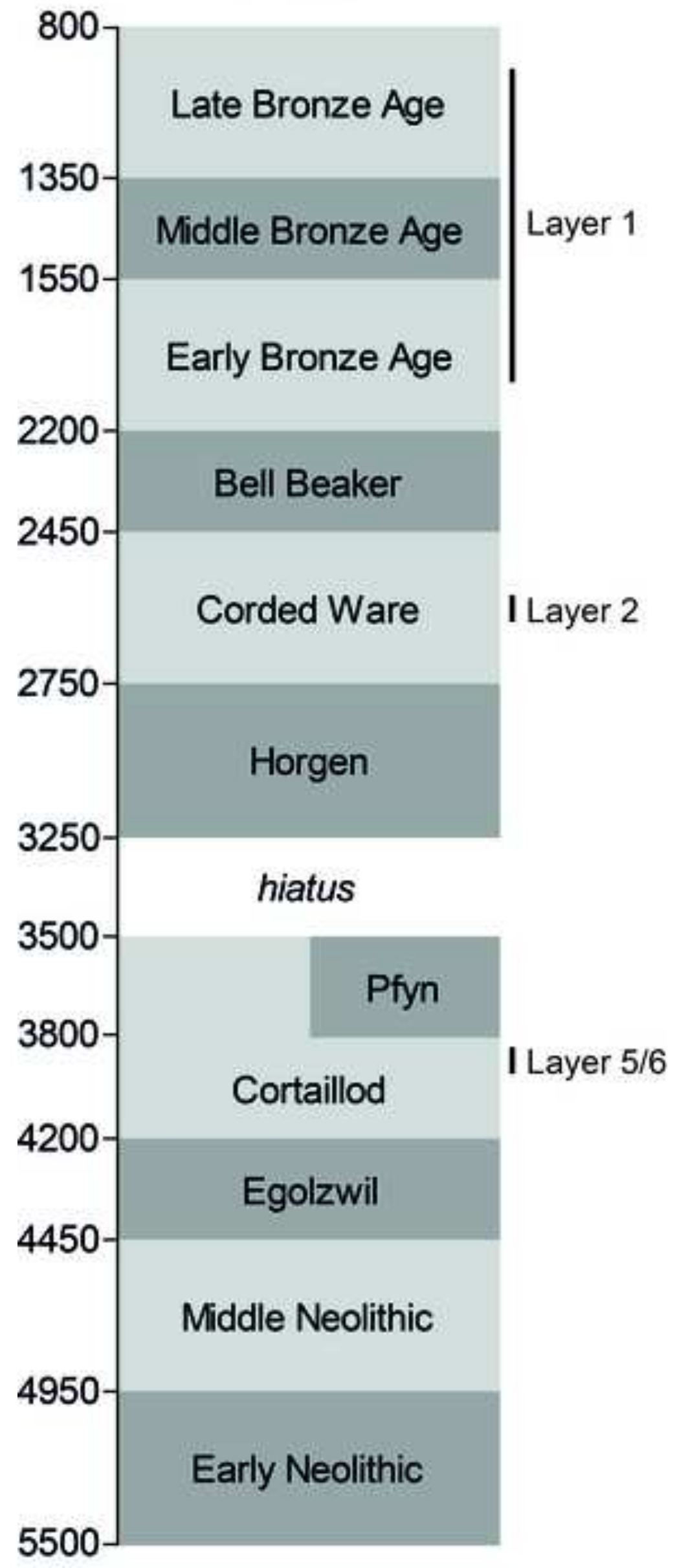


Figure 4

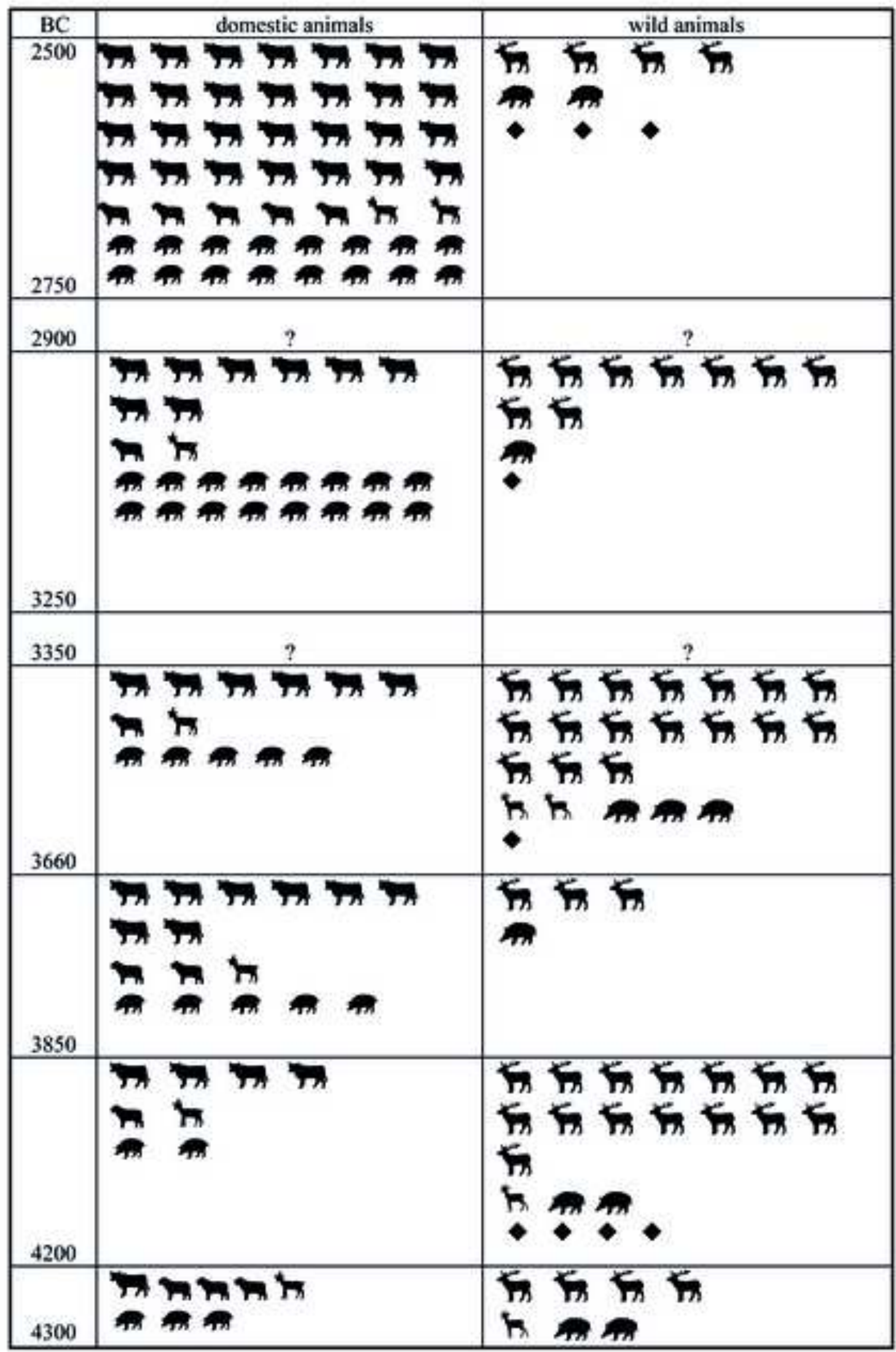




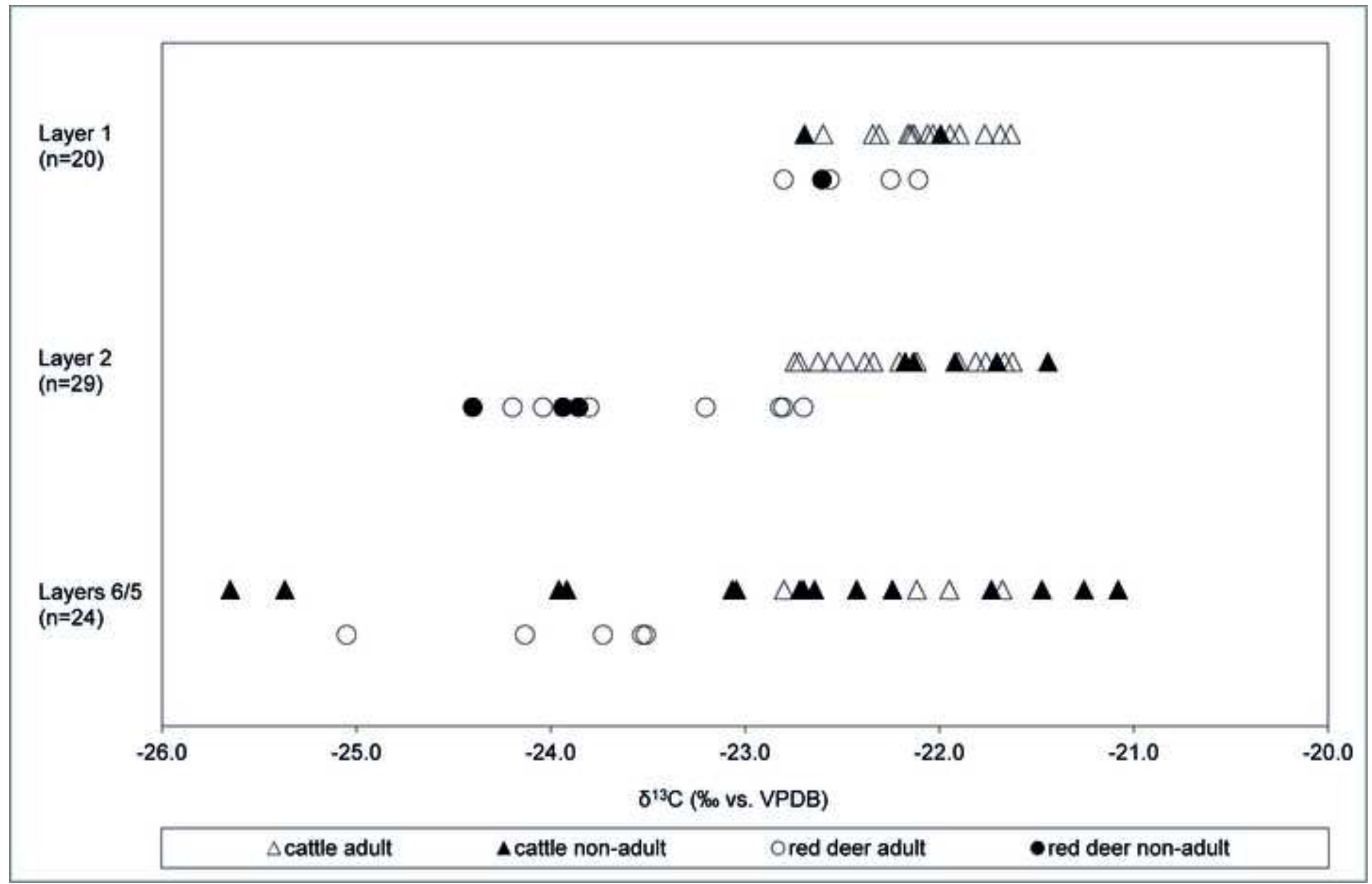




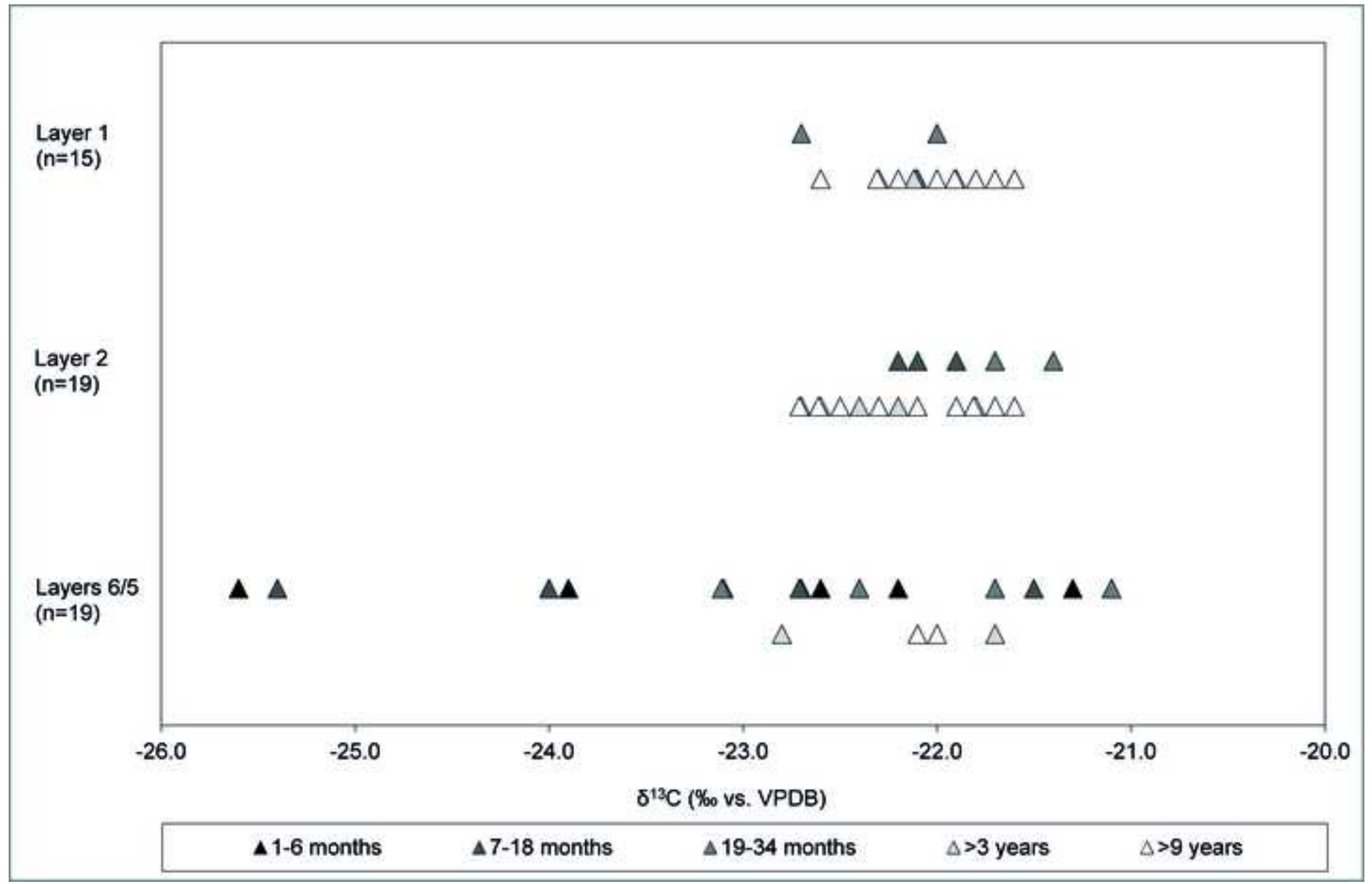




\begin{tabular}{|c|c|c|c|c|c|c|c|c|c|c|}
\hline Lab ID & Layer & Species & Skeletal element & Age & Age group & Coll\% & $\% \mathrm{C}$ & $\% \mathrm{~N}$ & $\mathrm{C} / \mathrm{N}$ & $\begin{array}{l}\delta^{13} \mathrm{C} \% \mathrm{o} \\
\text { (vs. VPDB) }\end{array}$ \\
\hline MOZ 19 & 1 & cattle & mandible right & $25-34 \mathrm{~m}$ & non-adult & 10.3 & 43.1 & 15.3 & 3.3 & -22.7 \\
\hline MOZ 33 & 1 & cattle & mandible right & ca. 3 y & non-adult & 12.4 & 43.5 & 15.5 & 3.3 & -22.0 \\
\hline MOZ 1 & 1 & cattle & mandible right & ca. 6.5 y & adult & 12.0 & 43.9 & 15.6 & 3.3 & -22.1 \\
\hline MOZ 3 & 1 & cattle & mandible right & ca. 6.5 y & adult & 10.9 & 43.8 & 15.7 & 3.3 & -22.1 \\
\hline MOZ 5 & 1 & cattle & mandible left & ca. $6.5 \mathrm{y}$ & adult & 12.3 & 43.7 & 15.6 & 3.3 & -22.1 \\
\hline MOZ 2 & 1 & cattle & mandible right & ca. 9 y & adult & 11.0 & 44.6 & 16.0 & 3.2 & -21.9 \\
\hline MOZ 16 & 1 & cattle & mandible right & ca. 9 y & adult & 15.3 & 42.4 & 15.1 & 3.3 & -22.0 \\
\hline MOZ 18 & 1 & cattle & mandible right & ca. 9 y & adult & 15.3 & 43.5 & 15.4 & 3.3 & -21.8 \\
\hline MOZ 20 & 1 & cattle & mandible right & ca. 9 y & adult & 13.3 & 42.7 & 15.1 & 3.3 & -22.3 \\
\hline MOZ 21 & 1 & cattle & mandible left & ca. 9 y & adult & 11.4 & 41.9 & 14.4 & 3.4 & -22.3 \\
\hline MOZ 22 & 1 & cattle & mandible left & ca. 9 y & adult & 9.1 & 41.1 & 14.4 & 3.3 & -22.6 \\
\hline MOZ 24 & 1 & cattle & mandible right & ca. 9 y & adult & 4.8 & 39.3 & 14.1 & 3.3 & -22.2 \\
\hline MOZ 4 & 1 & cattle & mandible left & ca. $11.5 \mathrm{y}$ & adult & 10.1 & 42.3 & 15.1 & 3.3 & -21.6 \\
\hline MOZ 17 & 1 & cattle & mandible right & ca. 11.5 y & adult & 10.7 & 42.5 & 15.2 & 3.3 & -21.7 \\
\hline MOZ 23 & 1 & cattle & mandible left & ca. $11.5 \mathrm{y}$ & adult & 10.2 & 42.3 & 15.0 & 3.3 & -21.9 \\
\hline MOZ 36 & 1 & red deer & mandible right & $11-12 \mathrm{~m}$ & non-adult & 13.7 & 43.2 & 15.3 & 3.3 & -22.6 \\
\hline MOZ 35 & 1 & red deer & mandible left & $>6 y$ & adult & 15.2 & 43.6 & 15.5 & 3.3 & -22.6 \\
\hline MOZ 6 & 1 & red deer & mandible left & $7-8 y$ & adult & 13.0 & 44.9 & 16.0 & 3.3 & -22.8 \\
\hline MOZ 7 & 1 & red deer & mandible left & $7-10 y$ & adult & 12.8 & 42.7 & 15.1 & 3.3 & -22.1 \\
\hline MOZ 34 & 1 & red deer & mandible right & adult & adult & 11.9 & 42.0 & 15.0 & 3.3 & -22.3 \\
\hline MOZ 53 & 2 & cattle & mandible left & $7-14 m$ & non-adult & 7.1 & 41.8 & 14.9 & 3.3 & -22.2 \\
\hline MOZ 81 & 2 & cattle & mandible left & 7-14 m & non-adult & 0.1 & 41.8 & 13.9 & 3.5 & -22.2 \\
\hline MOZ 44 & 2 & cattle & maxilla right & $15-18 m$ & non-adult & 9.0 & 41.5 & 14.8 & 3.3 & -21.9 \\
\hline MOZ 86 & 2 & cattle & maxilla left & $15-18 m$ & non-adult & 13.4 & 44.6 & 15.4 & 3.4 & -22.1 \\
\hline MOZ 51 & 2 & cattle & mandible left & $19-24 \mathrm{~m}$ & non-adult & 11.3 & 43.8 & 15.7 & 3.3 & -21.4 \\
\hline MOZ 56 & 2 & cattle & mandible left & $19-24 \mathrm{~m}$ & non-adult & 2.2 & 41.4 & 14.5 & 3.3 & -21.7 \\
\hline MOZ 54 & 2 & cattle & mandible left & $4-6.5 y$ & adult & 8.8 & 42.1 & 15.0 & 3.3 & -22.2 \\
\hline MOZ 79 & 2 & cattle & mandible right & $6.5-9$ y & adult & 7.8 & 44.1 & 15.6 & 3.3 & -22.4 \\
\hline MOZ 45 & 2 & cattle & maxilla right & ca. 9 y & adult & 17.1 & 43.1 & 15.5 & 3.2 & -22.6 \\
\hline MOZ 55 & 2 & cattle & mandible left & ca. 9 y & adult & 1.0 & 41.3 & 14.5 & 3.3 & -21.8 \\
\hline MOZ 83 & 2 & cattle & maxilla left & ca. 9 y & adult & 18.6 & 45.5 & 15.9 & 3.3 & -22.7 \\
\hline MOZ 48 & 2 & cattle & mandible left & $9-11.5$ y & adult & 9.0 & 41.7 & 15.0 & 3.2 & -22.3 \\
\hline MOZ 82 & 2 & cattle & maxilla left+right & $9-11.5$ y & adult & 16.3 & 45.7 & 16.1 & 3.3 & -22.5 \\
\hline MOZ 52 & 2 & cattle & mandible right & ca. 11.5 y & adult & 13.0 & 42.5 & 15.3 & 3.2 & -21.6 \\
\hline
\end{tabular}




\begin{tabular}{|lll|}
\hline Difference to be tested & p-value & Significance \\
\hline cattle and red deer (all layers) & $<0.0001$ & yes \\
adult and non-adult cattle (all layers) & 0.223 & no \\
adult and non-adult red deer (all layers) & 0.369 & no \\
cattle (layers 1 and 2) & 0.835 & no \\
cattle (layers 1 and 6/5) & 0.111 & no \\
cattle (layers 2 and 6/5) & 0.122 & no \\
red deer (layers 2 and 6/5) & 0.582 & no \\
red deer (layers 1 and 6/5) & 0.008 & yes \\
red deer (layers 1 and 2) & 0.004 & yes \\
\hline
\end{tabular}

